\title{
Prevalence of Dental Caries Among Residents of Bhopal City
}

\author{
Hiremath $\mathbf{V}^{1}$, Bhandari $\mathbf{V}^{2}$, Patil $\mathbf{A G}^{3}$, Kumar $\mathbf{S}^{4}$
}

\begin{abstract}
Aim: In present study we tried to analyze the role of different factors in the occurrence of dental caries.

Material \& Method: Oral examination was carried out in a sample of 2430 residents of Bhopal city, in various camps organized by Mansarovar Dental College in different location of Bhopal.
\end{abstract}

Results: Prevalence of dental caries was higher in males than in females, among tobacco users more prevalence of caries was found, persons with low socio economic status were having more carious lesions and people with mixed (vegetarian and non-vegetarian) diet.

Conclusion: Prevalence of dental caries in Bhopal city highlights the need for a dental health program to target specific segments of population through public health education program.

Keywords: Prevalence, Dental Caries.

\author{
${ }^{1}$ Professor \& Head \\ Department of Oral and Maxillofacial Pathology \\ Mansarovar Dental College Hospital and \\ Research Centre \\ Bhopal, Madyapradesh, India. \\ ${ }^{2}$ Lecturer \\ Department of Community dentistry \\ Mansarovar Dental College Hospital and \\ Research Centre \\ Bhopal, Madyapradesh, India. \\ ${ }^{3}$ Professor \& Head \\ Department of Prosthodontics \\ Mansarovar Dental College Hospital and \\ Research Centre \\ Bhopal, Madyapradesh, India. \\ ${ }^{4}$ Reader \\ Department of Oral and Maxillofacial Surgery \\ Mansarovar Dental College Hospital and \\ Research Centre \\ Bhopal, Madyapradesh, India.
}

\section{Contact Author}

Dr Vinaykumar Hiremath hvinay20012001@yahoo.com

J Oral Health Comm Dent 2015;9(2)64-68

\section{INTRODUCTION}

There are practically no geographic areas in the world whose inhabitants do not exhibit caries. Dental caries is considered as the most prevalent disease in humans secondly only to common cold. Various theories have been proposed to explain the etiology for dental caries. Lactobacillus acidophilus along with a combination of other bacteria such as streptococcus mutans and actinomyces species is closely associated with the causation of dental caries.

Dental caries is a disease with multifactorial causes, the prevalence and incidence of dental caries in a population is influenced by a number of risk factors such as age, sex, ethnic group, dietary patterns and oral hygiene habits. Despite several attempts to cure and prevent the disease its prevalence has increased over the last couple of decades. Present study was designed to assess the prevalence of dental caries in

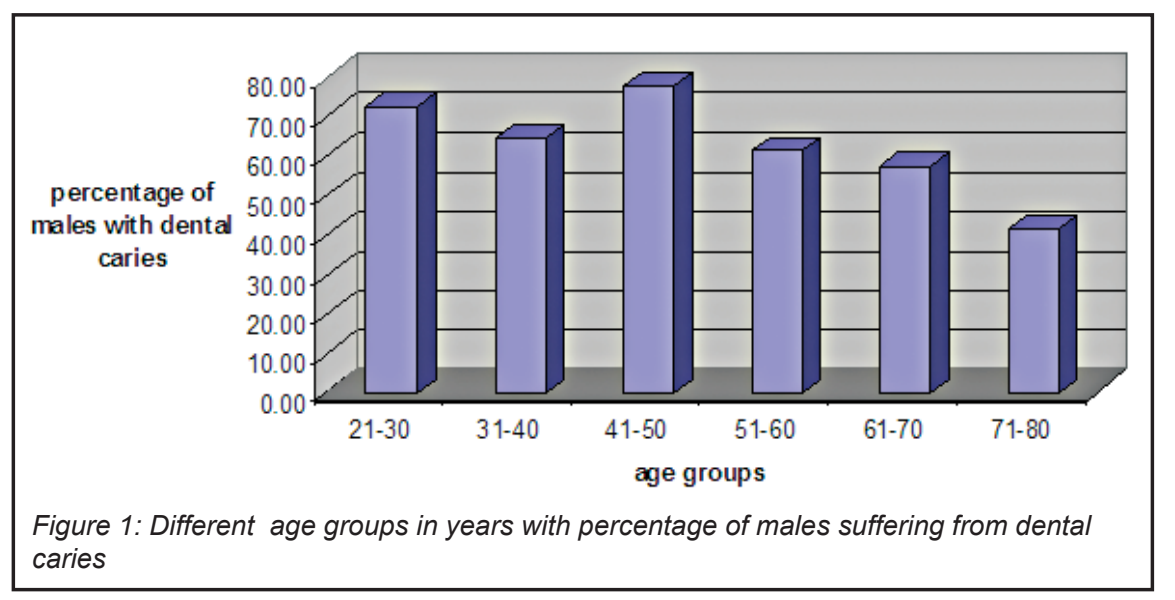


Table 1: Prevalence of Dental Caries in males

\begin{tabular}{lcccccc}
$\begin{array}{l}\text { Age } \\
\text { group }\end{array}$ & $\begin{array}{c}\text { No. of } \\
\text { patients } \\
\text { Male }\end{array}$ & $\begin{array}{c}\text { No. of } \\
\text { patients } \\
\text { with dental } \\
\text { caries }\end{array}$ & $\begin{array}{c}\text { No } \\
\text { caries }\end{array}$ & $\begin{array}{c}\text { Per- } \\
\text { centage }\end{array}$ & $\begin{array}{c}\text { Chi } \\
\text { squ }\end{array}$ & $\begin{array}{c}\text { p } \\
\text { value }\end{array}$ \\
\hline $21-30$ & 225 & 163 & 62 & 72.44 & & \\
\hline $31-40$ & 296 & 191 & 105 & 64.53 & & \\
\hline $41-50$ & 294 & 229 & 65 & 77.89 & 33.148 & $<0.0001$ \\
\hline $51-60$ & 197 & 121 & 76 & 61.42 & & \\
\hline $61-70$ & 89 & 51 & 38 & 57.30 & & \\
\hline $71-80$ & 24 & 10 & 14 & 41.67 & & \\
\cline { 1 - 4 } & & & & & &
\end{tabular}

Bhopal city.

Most of the Indian studies that have been published focused on school children $(1,2)$ and only a few studies have been done amongst adults $(3,4)$. This study was performed on adult residents of Bhopal.

\section{MATERIALS AND METHODS}

A cross sectional community based

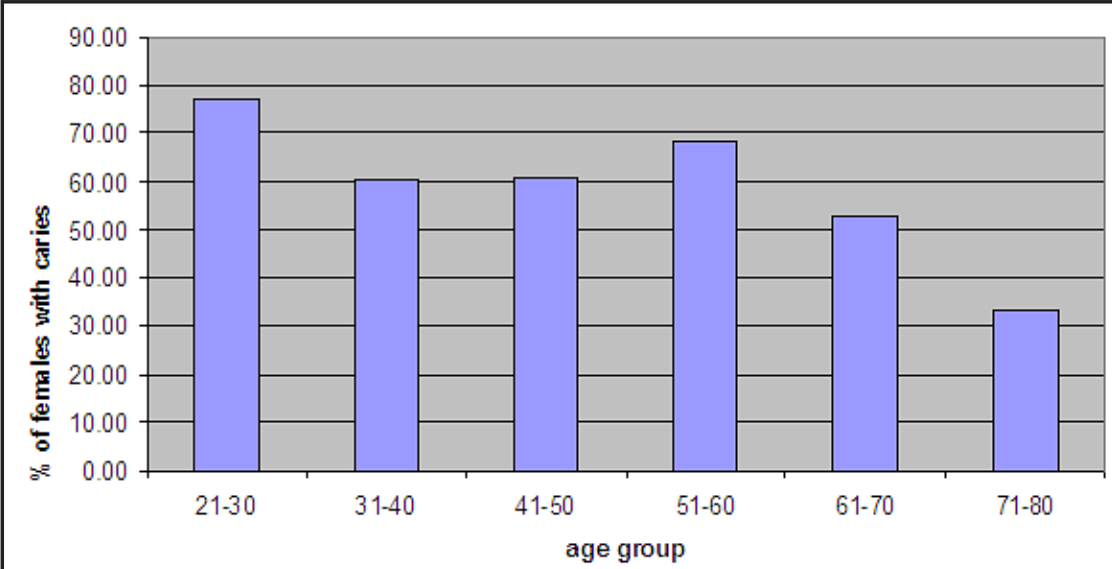

Figure 2 : Different age groups in years with percentage of females suffering from dental caries

\section{Table 2: Relationship between age group \& Dental caries}

\begin{tabular}{|c|c|c|c|c|c|c|}
\hline $\begin{array}{l}\text { Age } \\
\text { group }\end{array}$ & $\begin{array}{l}\text { No. of } \\
\text { patients } \\
\text { Female }\end{array}$ & $\begin{array}{c}\text { No. of } \\
\text { patients } \\
\text { with dental } \\
\text { caries }\end{array}$ & $\begin{array}{l}\text { No } \\
\text { caries }\end{array}$ & $\begin{array}{c}\text { Per- } \\
\text { centage }\end{array}$ & $\begin{array}{l}\text { Chi } \\
\text { squ }\end{array}$ & $\begin{array}{c}p \\
\text { value }\end{array}$ \\
\hline $21-30$ & 222 & 171 & 51 & 77.03 & & \\
\hline $31-40$ & 347 & 209 & 138 & 60.23 & & \\
\hline $41-50$ & 402 & 246 & 156 & 61.19 & 34.292 & $<0.0001$ \\
\hline $51-60$ & 216 & 148 & 68 & 68.52 & & \\
\hline $61-70$ & 100 & 53 & 47 & 53.00 & & \\
\hline $71-80$ & 18 & 6 & 12 & 33.33 & & \\
\hline
\end{tabular}

nutritious diet as per the protocol of the study after examination. Dental caries is a chronic disease and take a long time to de-mineralize the dental enamel, but the patients were asked for duration from when they are feeling visual symptoms like discoloration and questioned for any feeling of sensitivity or pain. Patients consent was taken and oral examination was conducted using a disposable illuminated mouth mirror and a blunt ball ended probe with an end diameter of $0.5 \mathrm{~mm}$. All teeth were examined in a systemic manner using FDI nomenclatures. Only definite cavitations of the tooth surface were regarded as dental caries to reduce examination confusion regarding diagnosis and exclusion of intact de-mineralized lesion. Patients were asked to rinse mouth thoroughly before examination, then the teeth were dried with cotton swab and dental caries were recorded. DMFT index was used where $D$ represents number of decayed teeth, $M$ is the number of missing teeth and $\mathrm{F}$ is the number of filled teeth and $T$ is used to denote tooth. Chi square test and $\mathrm{Z}$ test were used and $p$ value was taken out. Patients were referred to Mansarovar Dental College for further treatment.

\section{RESULTS}

During this study we tried to analyze the number of persons affected with dental caries in different gender, age, dietary habit, tobacco intake, socioeconomic status. Occurrence of dental caries was found to be higher in males with age group 41-50 years when compared (Fig 1) (Table 1). Females showed higher prevalence as compared to males, age group between 21-30 years showed higher prevalence than the other age group, (Fig 2) (Table 2). We also compared the dental caries in person with different dietary factors. We found that caries were more in people consuming a non vegetarian diet (fig 3 ) (table 3). We also compared presence of dental caries in tobacco users and non tobacco users. Occurrence was found to be more in tobacco users (fig $4,5)($ table 4,5$)$. Study was also done 


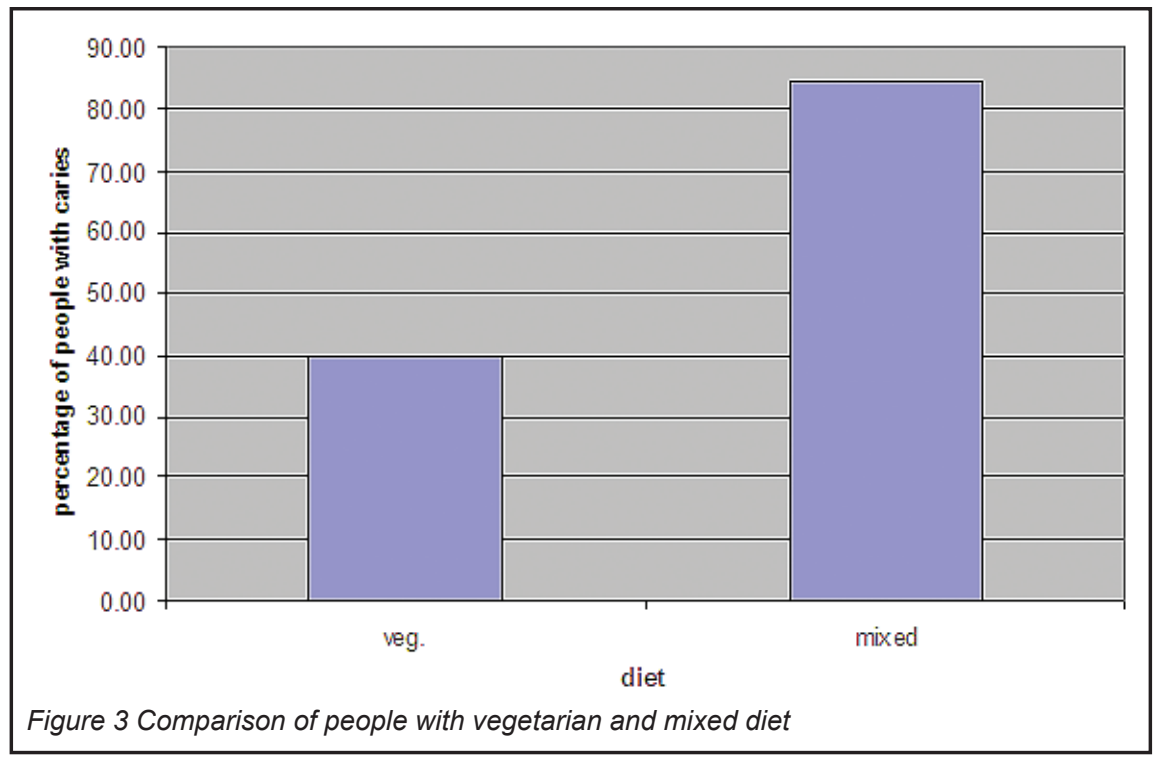

\section{Table 3: Relationship between Diet and Dental caries}

\begin{tabular}{lcccccc}
$\begin{array}{l}\text { Diet } \\
\text { habit }\end{array}$ & $\begin{array}{c}\text { No. of } \\
\text { patients }\end{array}$ & $\begin{array}{c}\text { Patients } \\
\text { with } \\
\text { caries }\end{array}$ & $\begin{array}{c}\text { Not } \\
\text { caries }\end{array}$ & $\begin{array}{c}\text { Per- } \\
\text { centage }\end{array}$ & $\begin{array}{c}\text { Chi } \\
\text { squ }\end{array}$ & $\begin{array}{c}\text { p } \\
\text { value }\end{array}$ \\
\hline Veg. & 1021 & 408 & 613 & 39.96 & & \\
\hline & & & & & 520.582 & $<0.0001$ \\
\hline Mixed & $\mathbf{1 4 0 9}$ & $\mathbf{1 1 9 0}$ & $\mathbf{2 1 9}$ & $\mathbf{8 4 . 4 6}$ & &
\end{tabular}

to evaluate correlation between dental caries and the socioeconomic status and occurrence was found to be more in low socioeconomic status (fig 6) (table 6). Distribution of caries according to the type was considered, occlusal pit and Fissure caries was predominantly seen (fig 7)

\section{DISCUSSION}

Dental caries a multi-factorial disease influenced by many factors including age, sex(5), diet, microorganisms, traceelements, saliva, genetic predisposition and tooth morphology $(6,7)$.

The grouping of subjects according to

\section{Table 4: Association between tobacco consumption \& Dental caries}

$\begin{array}{lccccccc}\begin{array}{l}\text { Tobacco } \\ \text { consumption }\end{array} & \begin{array}{c}\text { No. of } \\ \text { individuals } \\ \text { with dental } \\ \text { caries }\end{array} & \begin{array}{c}\text { \%. Of } \\ \text { individuals } \\ \text { with dental } \\ \text { caries }\end{array} & \begin{array}{c}\text { No. of } \\ \text { individuals } \\ \text { without } \\ \text { caries }\end{array} & \begin{array}{c}\text { \% Of } \\ \text { individuals } \\ \text { without } \\ \text { caries }\end{array} & \text { Total } & \begin{array}{c}\text { Chi } \\ \text { squ }\end{array} & \begin{array}{c}\text { P } \\ \text { value }\end{array} \\ \text { Yes } & 954 & 75.96 & 302 & 24.04 & 1256 & 119.988 & <0.0001 \\ \text { No } & 644 & 54.86 & 530 & 45.14 & 1174 & & \\ \text { Total } & 1598 & 65.76 & 832 & 34.24 & 2430 & & \end{array}$

\section{Table 5 : Association between Socio economic status \& dental caries}

\begin{tabular}{lcccccc}
$\begin{array}{l}\text { Socio } \\
\text { economic } \\
\text { status }\end{array}$ & $\begin{array}{c}\text { No. of } \\
\text { patients }\end{array}$ & $\begin{array}{c}\text { No. of } \\
\text { patients with } \\
\text { dental caries }\end{array}$ & $\begin{array}{c}\text { Not } \\
\text { caries }\end{array}$ & $\begin{array}{c}\text { Per- } \\
\text { centage }\end{array}$ & $\begin{array}{c}\text { Chi } \\
\text { squ }\end{array}$ & $\begin{array}{c}\text { p } \\
\text { value }\end{array}$ \\
\hline Low & $\mathbf{1 5 4 0}$ & $\mathbf{1 0 9 7}$ & $\mathbf{4 4 3}$ & $\mathbf{7 1 . 2 3}$ & 55.926 & $<0.0001$ \\
\hline High & 890 & 501 & 389 & 56.29 & & \\
\hline
\end{tabular}

the socio-economic status encompasses the influence of income, education, and social environment. Prevalence of dental caries was high in low socio economic status because of their poor oral hygiene practice, lack of awareness, improper food intake and family status. This finding is similar to study conducted by Sogi. G and Baskar D.J (2001) which was found to be statistically significant(chi sq.value $119.98, \mathrm{p}<0.0001)(8)$. Out of the total participants 1125 were male and 1305 were female. $68 \%$ of male have dental
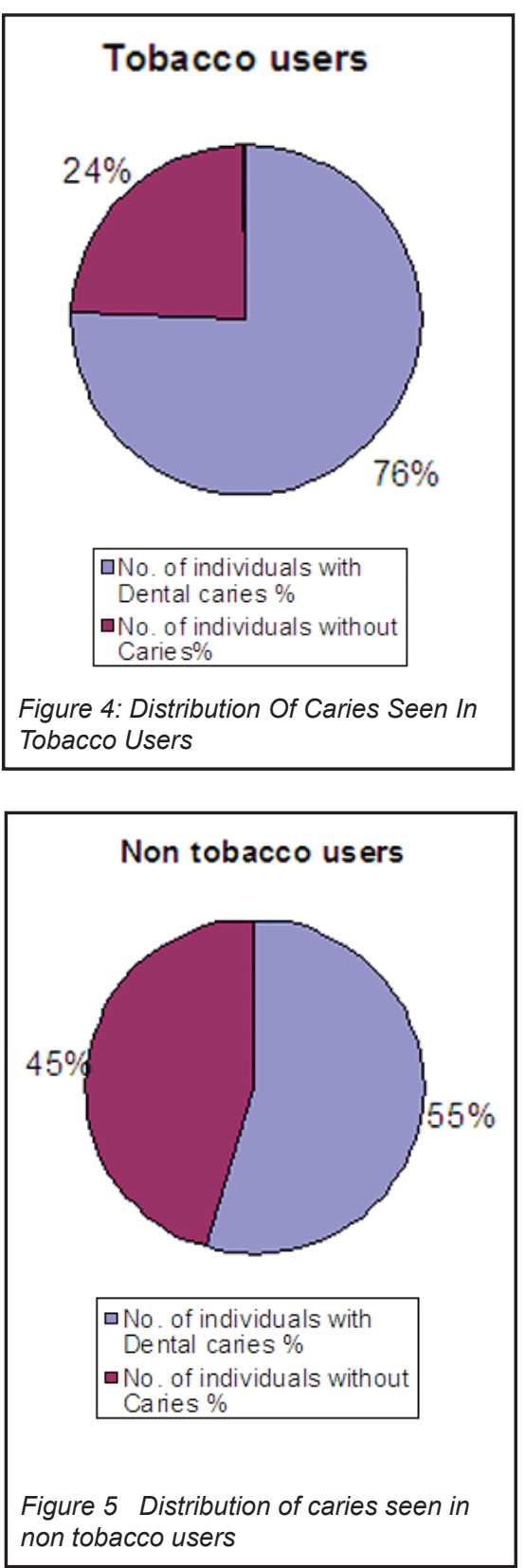


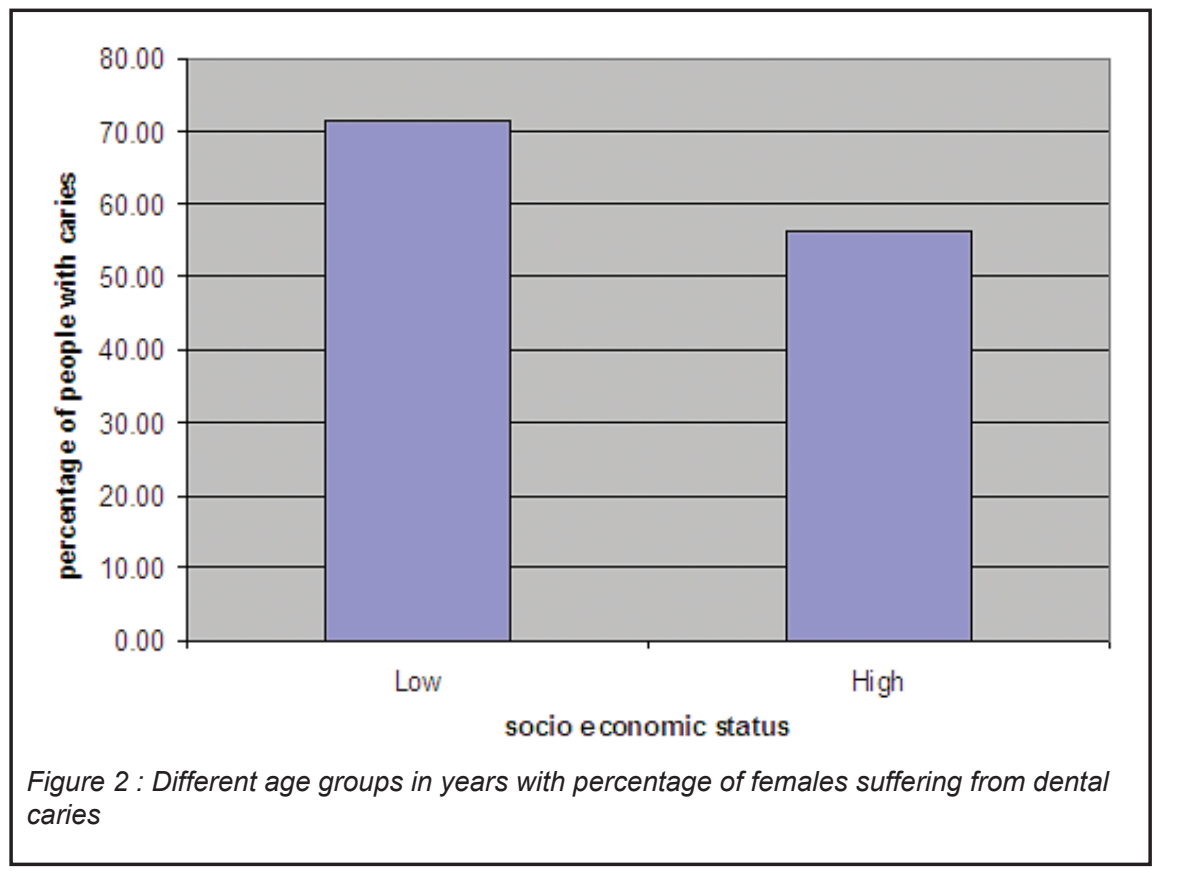

Table 6: Prevalence of Dental Caries by type

\begin{tabular}{lccccc} 
Type of Caries & $\begin{array}{c}\text { No. of } \\
\text { Patients }\end{array}$ & $\begin{array}{c}\text { No. of } \\
\text { Patients } \\
\text { with dental } \\
\text { caries }\end{array}$ & $\begin{array}{c}\text { Per- } \\
\text { centage }\end{array}$ & $\begin{array}{c}\text { Z Test of } \\
\text { proporation } \\
\text { (over all) }\end{array}$ & $\begin{array}{c}\mathbf{p} \\
\text { value } \\
\text { (over all) }\end{array}$ \\
\hline Root caries & 128 & 8.0 & & \\
\hline Recurrent caries & 16 & 1.0 & Z Value $>1.96$ & $<0.05$ \\
\hline Smooth surface caries & 207 & 13.0 & & \\
\hline $\begin{array}{l}\text { Occlusal Pit \& } \\
\text { Fissure caries }\end{array}$ & $\mathbf{1 2 4 7}$ & $\mathbf{7 8 . 0}$ & & \\
\end{tabular}

caries and $63.8 \%$ of female have dental

Distribution of caries according to type

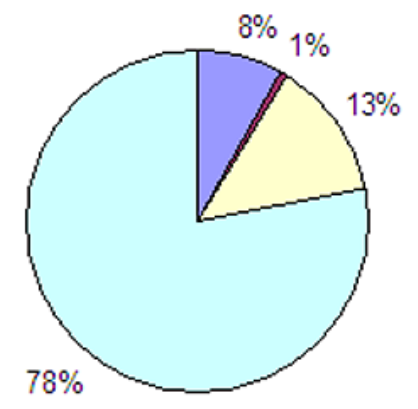

$\square$ root caries

$\square$ recurrent caries

$\square$ smooth surface caries

$\square$ occlusal pit \& fissure caries

Figure 7: Distribution of caries according to type cally significant(chi sq. value119.988,p value $<0.0001$ ). Usage of smokeless tobacco shows positive contributing factor for higher incidence of dental caries. High levels of fermentable sugar and sweeteners in smokeless tobacco can stimulate growth of cariogenic bacteria $(12,13)$. Extracts from chewing tobacco with higher sugar content increased in vitro growth of lactobacillus. Decreased buffering effect and possible lower ph of saliva in smokers may indicate increased susceptibility to caries. Higher number of lactobacilli and streptococcus mutans in smokers may indicate caries susceptibility $(14,15)$. Higher incidence of caries is experienced by the use of tobacco in any form (16). Root surface caries is usually related with poor health of gingival area, we have found relatively high occurrence of root caries among males including tobacco chewers, which usually results in unhealthy gingival. Highest prevalence of occlusal pits and fissure caries which was found to be statistically significant ( $Z$ test of proportion was applied, $Z>1.96, \mathrm{p}$ value $<0.05)$ can be correlated with the architecture of these sites, which is more retentive to carry food substances and is not fully exposed to flushing action of saliva. The bio-film tends to form and mature in these locations on the tooth including approximal surface cervical to the contact point, and along the gingival margin especially during eruption. These areas are relatively protected from mechanical wear by tongue, cheeks, abrasive food, and tooth brushing3. Thus, these are the sites where caries lesions may become visible. Similar observations have been obtained by many scientists indicating that, there is a relative lack of proper preventive procedures for such type of caries.

\section{CONCLUSION}

High caries prevalence in the sub-urban area of Kolar indicates enormity of oral health problems and low awareness about oral health, study revealed need for accessible and affordable oral health 
services. This work is a small effort towards understanding factors associated with dental caries. Caries prevention is based upon attempts to increase the resistance of the host, lower the number of micro-organisms in contact with the tooth and modify the substrate by selecting non-cariogenic food-stuff and reduce the time that substrate is in the mouth by limiting frequency of intake. Further studies comprising larger sample size and factors affecting dental caries are suggested.

\section{REFERENCES}

1. Vacher BR. Dental Survey of School Children in Amritsar, J.I.D.A.-1952;24:2-13

2. Mahesh Kumar $P$ et al. Oral health status of 5 years and 12 years school going children in Chennai city: An epidemiological study. J Indian Society Pedod Prev Dent 2005;23:17-22.

3. Shah N, Sundaram KR. Impact of socio demographic variables oral hygiene practices oral habits and diet on dental caries experiences of Indian elderly: A community based study. Gerodontology 2004;21:43-50

4. Thomas $\mathrm{S}$, et al. pattern of caries experience among an elderly population in south India. Int Dent J 1994;44:617-22.

5. Ad dy M, Dummer PMH, Hunter MI, Kigdon A, Shaw WC. The effect of tooth brushing frequency, tooth brushing hand, sex and social class on the incidence of plaque gingivitis and pocketing in adolescent. A longitudinal cohort study. Community dev. Health 1990;7:237-47.

6. Dash JK, Sahoo PK, Bhuyan SK, Sahoo SK. Prevalence of dental caries and treatment needs amongst children of Cuttack. J Ind Soc Prev Dent 2002;20: 139-43.

7. Kumar M, Chandu GN, Shafiualla MD. Oral health status and treatment needs in institutionalized psychiatric patients: One year descriptive cross sectional study. Indian J Dent Res 2006;17:171-77.

8. Sogi G, Baskar DJ. Dental Caries and oral hygiene status of 13-14 years old school children of Davangere. J Indian Soc Pedo Prev Dent 2001;19(3):113-17.

9. Aukland S, Bjelkaroey J. Dental health of school children in Betul district (MP) JIDA
1982:54:367-69.

10. Gangwar SK, Idris MZ, Bhushan V, Nirupam S, Saimbi CS, Jain JVC Biosocial correlates of dental caries. JIDA 1990;61:93-97.

11. Naseem Shah. Oral and Dental Diseasescauses, prevention and treatment strategies; $\mathrm{NCMH}$ background papers - Burden of diseases in India.

12. Tomar SL, Winn DM. Chewing tobacco use and dental caries among U.S. men, J Am Dental Association 1999; Nov.: 130 (11): 1601-10 Erratum in. J Am Dental Association 1999;130(12):1700.

13. Jacks SC, Schroeder KL, Rosens. In vitro effect of smokeless tobacco on cariogenic L Casei. J Dent Res 1989;68spec no: 390.

14. Kassirer B. Smoking as a risk factor for gingival problems, periodontal problems and caries. Univ Tor Dent J 1994;7(1): 6-10.

15. Axelsson P, Paulander J, Lindhe J. Relationship between smoking and dental status in 35-50, 65-75 year old individual. J Cler Periodontal 1996;25(4):297-305.

16. Thavarajah Rooban et al. Tooth decay in alcohol and tobacco abusers. Journal of Oral and Maxillofacial Pathology 2011;15(1). 